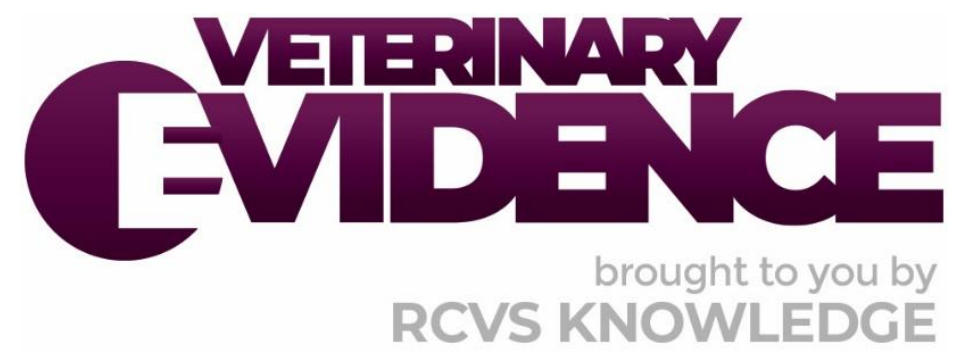

\title{
Comparison of alfaxalone versus propofol as anaesthetic induction agents in increasing the rate of survival and vigour of neonates
}

\section{A Knowledge Summary by}

Lesca Monica Sofyan BaAVBS(HonsII) MVS DVM ${ }^{1^{*}}$

Fernando Martinez Taboada LV CertVA PGCert(Biostats) DipECVAA ${ }^{2}$

\footnotetext{
${ }^{1}$ Orchard Hills Veterinary Hospital, 49-63 Wentworth Rd, Orchard Hills NSW 2748, Australia

${ }^{2}$ University Veterinary Teaching Hospital, School of Veterinary Science, The University of Sydney, 65 Parramatta Road, Camperdown, NSW 2050, Australia

*Corresponding Author (lesca.sofyan.xx@hotmail.com)
}

ISSN: 2396-9776

Published: 30 Jun 2021

in: The Veterinary Evidence journal Vol 6, Issue 2

DOI: https://doi.org/10.18849/ve.v6i2.344

Reviewed by: Jane Alexander (BVetMed CertVA MRCVS), Latifa Khenissi (DVM MRCVS Dipl. ECVAA) and Tristan Merlin (MSc MVetMed MRCVS)

Next Review Date: 20 Nov 2022 


\section{KNOWLEDGE SUMMARY}

\section{PICO question}

In routine canine caesareans, is alfaxalone a superior anaesthetic induction agent than propofol in increasing the rate of survival and vigour of neonates?

\section{Clinical bottom line}

\section{Category of research question}

\section{Treatment}

\section{The number and type of study designs reviewed}

Three randomised positive clinical trials have compared the efficacy between alfaxalone and propofol in routine canine caesarean sections for increased neonatal survival and vigour

\section{Strength of evidence}

Weak

\section{Outcomes reported}

Although two studies found alfaxalone to be associated with higher Apgar scores for neonates than propofol, each study nonetheless revealed positive vigour and high survival rates from the use of either alfaxalone or propofol. The evidence is too weak to suggest that one induction agent is superior to another. The selection between the two induction agents may not be the main concern in regard to neonatal depression and 24 hour survival post-delivery, provided that the entire canine caesarean protocol is thoroughly and carefully studied

\section{Conclusion}

The evidence is too weak to suggest that alfaxolone or propofol is superior to another during canine cesareans. There is no signifcant difference seen in neonatal survival rate and vigour when using either alfaxolone or propofol

\section{How to apply this evidence in practice}

The application of evidence into practice should take into account multiple factors, not limited to: individual clinical expertise, patient's circumstances and owners' values, country, location or clinic where you work, the individual case in front of you, the availability of therapies and resources.

Knowledge Summaries are a resource to help reinforce or inform decision making. They do not override the responsibility or judgement of the practitioner to do what is best for the animal in their care. 


\section{Clinical Scenario}

You are presented with an 8 year old female entire Staffordshire Bull Terrier who is in dystocia. As you prepare for a caesarean, you recall that alfaxalone and propofol as induction agents have both been associated with positive neonatal survival and vigour according to published reports. To ensure best practice and aid in the development of a gold standard anaesthetic protocol for routine canine caesareans for your practice, you aim to research if one induction agent may be superior to one another in increasing neonatal survival and vigour.

\section{The evidence}

Three randomised, positive-controlled clinical trials were considered significant and relevant for the research. Each article directly compared alfaxalone and propofol in canine caesarean sections and analysed outcomes related to the welfare of the bitch, vigour and survival rate of the neonates.

\section{Summary of the evidence}

Doebeli et al. (2013)

\begin{tabular}{|c|c|}
\hline Population: & $\begin{array}{l}\text { - Female dogs booked in for emergency caesarean sections } \\
\text { that displayed indications for being at risk of dystocia } \\
\text { - Indications for dystocia included poor general condition of } \\
\text { the dam, neonates were in feto-maternal disproportion or } \\
\text { position, the heart rates of the neonates were considered } \\
\text { very low }(<180 \mathrm{bpm}) \text { or natural birthing would result in birth } \\
\text { canal obstruction of the dam. } \\
\text { - Bitches ranged from the age of } 1-11 \text { years. } \\
\text { - Body weight of the bitches ranged from } 1.6-51 \mathrm{~kg} \text {. }\end{array}$ \\
\hline Sample size: & 22 dogs \\
\hline Intervention details: & $\begin{array}{l}\text { Pre-medication } \\
\text { Not used in the study. } \\
\text { Pre-anaesthesia } \\
\text { - All animals received Ringer's lactate solution (10-20 } \\
\mathrm{mL} / \mathrm{kg} / \mathrm{hr} \text { ) immediately prior to anaesthesia. } \\
\text { - } \quad \text { Preoxygenation was conducted using a } 2 \mathrm{~L} \text { flow of oxygen for } \\
5 \mathrm{minutes} \text {, followed by an intravenous dose of cefazolin ( } 20 \\
\mathrm{mg} / \mathrm{kg} \text { ). } \\
\text { Treatment groups } \\
\text { - } \text { Bitches were randomly assigned to two treatment groups. } \\
\text { - } \text { rate between } 1-2 \mathrm{mg} / \mathrm{kg} \text { until tracheal intubation was } \\
\text { possible. } \\
\text { Propofol ( } \mathrm{n}=11 \text { ) was intravenously administered } 2-6 \mathrm{mg} / \mathrm{kg} \\
\text { until tracheal intubation was possible. } \\
\text { Surgeons assigned for the evaluation and outcome on the } \\
\text { vitality of the neonates were blinded and unaware of the } \\
\text { agent the bitch received during the procedure. } \\
\text { Anaesthesia } \\
\text { Maintained with isoflurane. }\end{array}$ \\
\hline
\end{tabular}




\begin{tabular}{|c|c|}
\hline & $\begin{array}{l}\text { Neonatal care } \\
\text { All puppies had the following protocols carried out immediately } \\
\text { upon delivery: } \\
\text { - Fluid suctioned from the upper airway } \\
\text { - Rubbed and blow-dried with warm bedding } \\
\text { - Oxygenated at a flow of } 2 \mathrm{~L} / \mathrm{min} \\
\text { - In the emergency case where a neonate was not breathing, } \\
\text { gentle mouth-to-mouth breathing was performed. An } \\
\text { analeptic was also administered at a dosage of } 1-2 \mathrm{drops} \\
\text { orally along with a subcutaneous bolus of warm } 5 \% \text { glucose } \\
\text { or resuscitation } \\
\text { - Umbilical cord ligated } 0.5-1 \mathrm{~cm} \text { from the abdominal wall and } \\
\text { disinfected with a weak iodine solution } \\
\text { - All neonates were placed in a newborn incubator }\end{array}$ \\
\hline Study design: & Double blinded and randomised positive-controlled trial \\
\hline Outcome studied: & 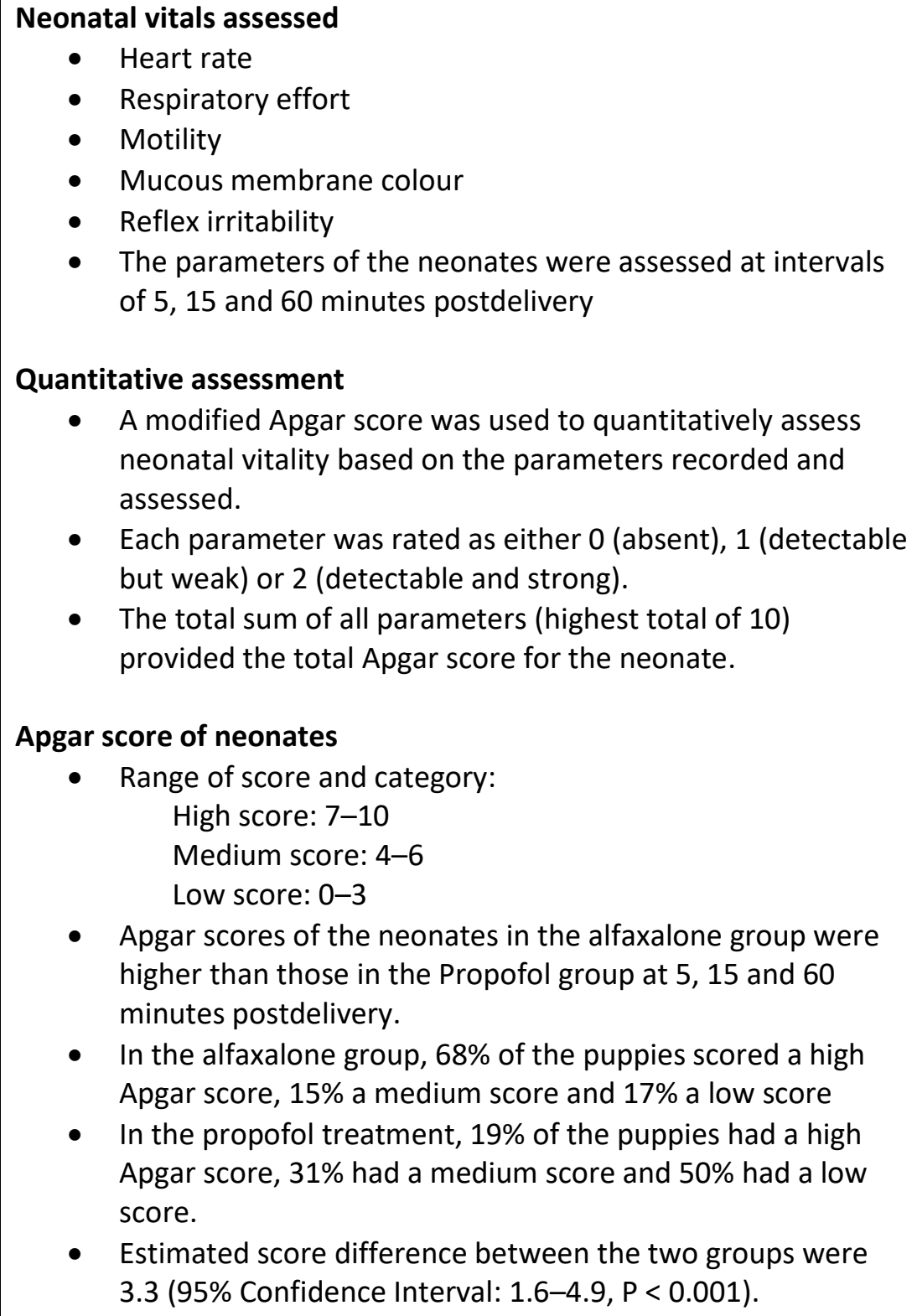 \\
\hline
\end{tabular}




\begin{tabular}{|c|c|}
\hline & $\begin{array}{l}\text { Assessment of preoperative parameters } \\
\text { Age, parity, body weight, heart rate, respiratory rate, packed cell } \\
\text { volume, total protein and temperature did not differ between the } \\
\text { alfaxalone and propofol group. } \\
\text { Assessment of intra-operative parameters } \\
\text { Temperature, anaesthetic duration, heart rate, mean blood } \\
\text { pressure, delivery time and puppies delivered by caesarean did not } \\
\text { differ between the alfaxalone and propofol. }\end{array}$ \\
\hline $\begin{array}{l}\text { Main findings: } \\
\text { (relevant to PICO question): }\end{array}$ & $\begin{array}{l}\text { - Puppies delivered from dogs induced with alfaxalone scored } \\
\text { a significantly higher modified Apgar score than those } \\
\text { induced with propofol. } \\
\text { - Important finding as the vitals and response of neonates } \\
\text { upon delivery will determine rapid colostrum uptake and } \\
\text { overall survival. }\end{array}$ \\
\hline Limitations: & $\begin{array}{l}\text { - Apgar score can be subjective. } \\
\text { - } \text { Did not claim if it was the first time the bitches had } \\
\text { - No attempt to calculate an adequate sample size. } \\
\text { - No information provided regarding the duration of labour } \\
\text { prior to caesarean. } \\
\text { - No indication regarding preoperative fetal suffering. } \\
\text { - No separation between urgent and non-urgent cases. } \\
\text { - } \quad \text { caesarean. }\end{array}$ \\
\hline
\end{tabular}

Metcalfe et al. (2014)

\begin{tabular}{|c|c|}
\hline Population: & $\begin{array}{l}\text { - Female dogs presented for routine caesareans. } \\
\text { - Cases were obtained over an } 8 \text { month period in three } \\
\text { Australian states - Western Australia, Victoria and } \\
\text { Queensland. } \\
\text { - No set inclusion/exclusion criteria in regard to the age and } \\
\text { weight of the patients. }\end{array}$ \\
\hline Sample size: & Total sample size $n=74$ \\
\hline Intervention details: & $\begin{array}{l}\text { Treatment groups } \\
\text { - Each dam was randomly assigned to receive alfaxalone or } \\
\text { propofol. Allocation was randomised in blocks of three. } \\
\text { - } 2 / 3 \text { cases would be assigned to the alfaxalone treatment } \\
\text { group and one out of three cases would be assigned to the } \\
\text { propofol treatment group. } \\
\text { - Group } 1(\mathrm{n}=48): \text { Alfaxalone was intravenously administered } \\
\text { at a dose rate of } 2 \mathrm{mg} / \mathrm{kg} \text { over } 60 \text { seconds. } \\
\text { - Group } 2(\mathrm{n}=26): \text { Propofol was intravenously administered } \\
\text { at a dose rate } 7 \mathrm{mg} / \mathrm{kg} \text { over } 60 \text { seconds. } \\
\text { - Seven veterinarians were assigned to evaluate the condition } \\
\text { of the dam and neonates. However, they were not blinded } \\
\text { to the assignment and aware of the induction agent the } \\
\text { patient received. }\end{array}$ \\
\hline
\end{tabular}




\begin{tabular}{|c|c|}
\hline & $\begin{array}{l}\text { Premedication } \\
\text { No bitch received premedication to reduce potential confounding } \\
\text { effects it may have on the induction agents. } \\
\text { Anaesthesia } \\
\text { Maintained with isoflurane. }\end{array}$ \\
\hline Study design: & Multicentre, randomised positive-controlled clinical trial \\
\hline Outcome studied: & $\begin{array}{l}\text { Induction, maintenance and recovery scoring criteria } \\
\text { - Respiratory rate, pulse rate and oxygen saturation of } \\
\text { haemoglobin measurements of the bitch were recorded } \\
\text { after induction, during the maintenance of anaesthesia and } \\
\text { recovery phases - this does not address the PICO question } \\
\text { and therefore will not be commented on any further in this } \\
\text { Knowledge Summary. } \\
\text { - Assessment of the induction and maintenance phases } \\
\text { included a subjective descriptive outline that was classified } \\
\text { as either excellent, good or unacceptable. } \\
\text { - Assessment for recovery included a descriptive outline of } \\
\text { what was considered excellent, good, fair and poor. } \\
\text { Neonatal assessment } \\
\text { - Puppies were assessed as either live or dead upon delivery. } \\
\text { The withdrawal reflex, sucking reflex, anogenital response } \\
\text { and flexion reflex of the neonates were also assessed and } \\
\text { scored as either present or negative. } \\
\text { Neonatal survival at } 24 \text { hours } \\
\text { After } 24 \text { hours since delivery, each puppy was reassessed as either } \\
\text { alive or dead. }\end{array}$ \\
\hline $\begin{array}{l}\text { Main findings: } \\
\text { (relevant to PICO question): }\end{array}$ & $\begin{array}{l}\text { - There was no statistical significance in the puppies' } \\
\text { withdrawal reflex, suction reflex, anogenital reflex and } \\
\text { flexion reflex between the alfaxalone and propofol group ( } P \\
=0.5 .0 .9,0.6,0.8 \text { respectively). } \\
\text { - Survival of puppies } 24 \text { hours after birth did not differ } \\
\text { significantly between the alfaxalone }(96.2 \%) \text { and propofol } \\
\text { group }(94.7 \%)(P=0.7) \text {. }\end{array}$ \\
\hline Limitations: & $\begin{array}{l}\text { - Veterinarians were not blinded to which induction agent } \\
\text { each patient received introducing sources of bias. } \\
\text { - The sample size of the two treatment groups were not equal } \\
\text { resulting in distortion and variance across the results. } \\
\text { - No use of the modified Apgar score that has been of } \\
\text { traditional use in previous studies. } \\
\text { - No information regarding blood pressure under general } \\
\text { anaesthesia that may have affected uterine perfusion and } \\
\text { oxygen delivery. } \\
\text { - No indication regarding pre-operative fetal suffering. } \\
\text { - No separation between urgent and non-urgent cases. } \\
\text { No information regarding the duration of labour prior to } \\
\text { caesarean. }\end{array}$ \\
\hline
\end{tabular}


- No mention of pre-anesthetic preoxygenation despite numerous cases of post-induction apnea.

- Survival only studied at $24 \mathrm{~h}$ postdelivery.

Melandri et al. (2019)

Population: Criteria for inclusion and eligibility

- Giant size purebred bitches belonging to the breeds Great Dane, Newfoundland, Maremmano, Saint Bernard.

- Bitches weight between 53-75 kg.

- Pregnancies without complications showing normal fetal development assessed by fetal biometry.

- Planned routine caesareans.

- All bitches were fed the same commercial diet according to metabolic requirements for gestation.

\section{Criteria for exclusion}

Pregnancies with complications.

Sample size:

Total sample size $n=10$

Intervention details:

\section{Treatment groups}

- Each dam was assigned to receive alfaxalone or propofol by the anaesthetist via casual randomisation

- Bitches with an odd enrolment number were assigned to group A (alfaxolone).

- Bitches with an even enrolment number were assigned to group $P$ (propofol)

- Group A: $(n=5)$ Alfaxalone was intravenously administered at a dose rate of $3 \mathrm{mg} / \mathrm{kg} \mathrm{IV}$ and titrated until able to effectively reach oro-tracheal intubation.

- Group P: $(n=5)$ Propofol was intravenously administered at a dose rate $4 \mathrm{mg} / \mathrm{kg}$ IV and titrated until able to effectively reach oro-tracheal intubation.

\section{Operating team}

Surgeons, neonatologists, and individual to collect fetal fluids were blind to the inductor agent used by the anaesthetist.

\section{Fasting}

Bitches were fasted for 12 hours before surgery.

\section{Premedication}

No bitch received premedication to reduce potential confounding effects it may have on the induction agents.

\section{Pre-anaesthesia}

- All bitches received 5 minutes preoxygenation.

- All bitches received $5 \mathrm{ml} / \mathrm{kg}$ of Ringer lactate intravenously.

\section{Anaesthesia}

- Maintained with isoflurane at $2 \%$. 


\begin{tabular}{|c|c|}
\hline & $\begin{array}{l}\text { - Oxygen concentration at } 90-95 \% \text {. } \\
\text { - Open circuit Mapelson type C was used. } \\
\text { Collection of amniotic and allantoic } \\
\text { - Amniotic and allantoic fluids were aseptically collected in } \\
\text { fetal bag openings. } \\
\text { - Only half of the total number of puppies from each litter was } \\
\text { sampled to reduce the mistake of fetal fluid identification } \\
\text { - } \text { and collection ( } \mathrm{n}=36 \text { ). } \\
\text { - Group A: } 16 \text { samples. } \\
\text { - Every second puppy was sampled to ensure an equal } \\
\text { representation of the puppies extracted at the beginning, in } \\
\text { the middle and the end of the procedure. } \\
\text { Postoperative medications } \\
\text { Opioid methadone } 0.2 \mathrm{mg} / \mathrm{kg} \text { intramuscular and NSAIDs meloxicam } \\
0.2 \mathrm{mg} / \mathrm{kg} \text { intramuscular were administered to the bitch after the } \\
\text { extraction of the last puppy. }\end{array}$ \\
\hline Study design: & Multicentre, randomised positive-controlled clinical trial \\
\hline Outcome studied: & $\begin{array}{l}\text { Neonate viability } \\
\text { Puppies were assessed with the Apgar score } 5 \text { minutes after birth } \\
\text { and defined as viable if scores were equal to or over } 7 \text {. } \\
\text { Fetal cortisol concentrations } \\
\text { - Fluids were immediately centrifuged at } 1000 \text { rpm for } 10 \text { min, } \\
\text { supernatant was removed, and samples were frozen at -20 } \\
{ }^{\circ} \text { C to be later analyzed by Radio-Immuno Assay (RIA) for } \\
\text { cortisol concentrations. } \\
\text { - Analysis was performed within } 3 \text { months from fluid } \\
\text { collection. } \\
\text { Statistical analysis } \\
\text { - ANOVA (Analysis of Variance), U Mann-Whitney test and } \\
\text { ANCOVA (Analysis of Covariance) to assess the difference } \\
\text { and effect of alfaxolone and propofol on Apgar scores and } \\
\text { fetal cortisol concentration. } \\
\text { - Results were considered significant if P }<0.05 \text {. }\end{array}$ \\
\hline $\begin{array}{l}\text { Main findings: } \\
\text { (relevant to PICO question): }\end{array}$ & $\begin{array}{l}\text { - No significant difference in fetal cortisol concentrations } \\
\text { between amniotic and allantoic fluids between the } \\
\text { alfaxolone and propofol treatment groups }(P>0.05) \text {. } \\
\text { - Apgar scores were statistically significantly higher in } \\
\text { alfaxolone treatment group than the Propofol treatment } \\
\text { group }(P<0.02) \text {. } \\
\text { - The median value of the Apgar score in the alfaxolone group } \\
\text { was } 10 \text { whilst in the propofol group was } 9 \text {. } \\
\text { - Amniotic and allantoic fluid cortisol concentrates are } \\
\text { significant co-variates on the relationship existing between } \\
\text { the induction agent }(P=001) \text { and Apgar score }(P=0.004) \text {. }\end{array}$ \\
\hline
\end{tabular}




\begin{tabular}{|l|l|}
\hline Limitations: & - Small sample size. \\
& Puppies delivered last would be subjected to isoflurane for \\
& longer periods than puppies delivered earlier thus \\
& introducing potential bias and affecting Apgar scores and \\
& cortisol concentrations. \\
& Clinical significance of the covariance existing between \\
& amniotic and allantoic fluid cortisol levels, induction agent \\
& and Apgar score is unclear. \\
- & No record or analysis on how the concentration of isoflurane \\
& was modified during course of caesarean and therefore a \\
& significant difference in mean isoflurane concentration \\
& between the two groups could have occurred. \\
- & No record or analysis of blood pressure measurements \\
& available thus a significant difference in blood pressure \\
concentration between the two groups could have occurred & No actual dose of how much induction was used in each \\
group recorded which may have been variable.
\end{tabular}

\section{Appraisal, application and reflection}

Blinding is an important and distinct feature in randomised controlled trials to reduce selection bias from affecting results ${ }^{17}$. Although Doebeli et al. (2013) and Melandri et al. (2019) did not thoroughly outline the methodology of blinding used in their study, it was still used in contrast to the study conducted by Metcalfe et al. (2014). This reduces the validity of the results in Metcalfe et al. (2014) as there may potentially show a selection bias. Patients and evaluators assigned to a treatment with knowledge and no concealment may deliberately select to disapprove or approve a treatment based on personal beliefs and influential factors ${ }^{18}$. Clinically, it is common for practitioners to favour a particular therapeutic drug over another for certain procedures. Blinding would have been crucial to evaluate the effect of the induction agents on the neonate vigour as this involves a subjective assessment. Perhaps, neonatal survival might not be so impacted as it is an objective measurement.

Although Metcalfe et al. (2014) had a larger sample size than Doebeli et al. (2013) and in particularly Melandri et al. (2019), the sample sizes across the three studies are still considerably small as neither reached a calculated sample size that would be considered the minimum standard and appropriate size in clinical research studies ${ }^{19}$. The three studies also did not provide details on how sample size was determined for it to be adequate for the study. Appropriate sample sizes are essential in providing a true representation of an underlying population and ensuring that the clinical question proposed is statistically adequate and satisfied ${ }^{19}$. Small sample sizes may not be sufficient to detect a true difference resulting in a false negative ${ }^{19}$. A higher number of patients were enrolled in the alfaxalone treatment group compared to the propofol treatment group in the clinical trial conducted by Metcalfe et al. (2014) and this may have potentially shifted and statistically favoured the effects of alfaxalone therefore, distorting an equal and fair representation.

The Apgar Score System for the evaluation of canine newborn viability has been, and currently is still favoured in canine obstetrics for its simplicity requiring a limited number of elements (stethoscope and physical examination), its ease to modify certain criteria if required and providing an immediate assessment of the neonate's physiological factors ${ }^{20,21}$. Each clinical study used and modified the Apgar score system with different sets of criteria to effectively assess the viability of the puppies immediately upon delivery. The modified Apgar score results utilised in each of the three studies depicted what would account as positive and favourable neonatal responses such as rapid capillary refill time, steady heart rate and respiratory rate, pink mucous membrane colour and positive reflexes. The limitation of using solely the Apgar Score System however is that interpretation of the criteria can be subjective as it is carried out qualitatively. The analysis of the 
neonatal vigour, stress and survival could have been strengthened in studies by Doebeli et al. (2013) and Metcalfe et al. (2014) with the additional use of further quantitative methodologies such us umbilical vein lactate, blood gas assessment and acid base $\mathrm{e}^{20,21,22}$. The combination of these quantitative markers along with the Apgar score would have been an advanced system in the evaluation of canine vitality ${ }^{22}$. Fortunately, Melandri et al. (2019) was able to calculate amniotic and allantois cortisol fluid concentrations as a quantitative marker for neonatal survival in the first 24 hours of life and identify it as a covariant with the Apgar score levels ${ }^{25}$. Fetal cortisol levels have been reported as a potentially useful marker in evaluating neonates at birth, particularly when combined with the Apgar score system ${ }^{24,25}$.

The use of premedication agents in caesarean sections is controversial. Small animal clinicians may avoid the use due to the risk of imposing further drug uptake in the neonates. Most premedicated agents used by small animal practice clinicians are an opioid (e.g. buprenorphine, butorphanol, methadone) combined with an $\alpha_{2^{-}}$ adrenergic agonist (e.g medetomidine) and it has been recommended for its benefits of providing pre-emptive analgesia, decreasing maternal stress and reducing the amount and dose of induction and maintenance agents $^{22}$. De Cramer et al. (2017) showed medetomidine hydrochloride was safely permitted to use as a premedication in caesarean sections as it was associated with good puppy vigour provided that reversal (atipamezole) was administered ${ }^{26}$. Although there is currently no information regarding the use of opioids as a necessity in caeserean sections, the three studies did not apply any premedication agents. This would have been beneficial and useful not only for the study but the vigour and survival of the bitch and her neonates, particularly with regards to providing a mode of analgesia prior to a surgical procedure.

Each study directly compared alfaxalone and propofol, which provided an accurate representation of the common induction agents used in small animal practice. Furthermore, all involved variable canine breeds which is representative of future patients that may be involved in caesarean procedures. Each clinical trial also effectively assessed neonatal vigour and rate of survival after the dam was induced with either alfaxalone or propofol. In conclusion to the clinical question proposed and critical analysis of the available three studies, there is no strong evidence to suggest that one induction agent, either alfaxolone or propofol, is superior to another to use during caesarean sections.

\section{Methodology Section}

\begin{tabular}{|c|c|}
\hline \multicolumn{2}{|l|}{ Search Strategy } \\
\hline $\begin{array}{r}\text { Databases searched and dates } \\
\text { covered: }\end{array}$ & $\begin{array}{l}\text { CAB Abstract database via Web of Science (1973-2019) } \\
\text { PubMed database accessed via the NCBI platform (1910-2019) }\end{array}$ \\
\hline Search terms: & $\begin{array}{l}\text { (dog OR dogs OR bitch OR bitches OR canine OR canines) AND } \\
\text { (caesarean OR caesarean sections OR c-section OR cesarean) AND } \\
\text { (Alfaxalone or Alfaxan or Alphaxalone or Alphaxolone) AND } \\
\text { (Propofol) }\end{array}$ \\
\hline Dates searches performed: & 20 Nov 2020 \\
\hline
\end{tabular}

\section{Exclusion / Inclusion Criteria}

\begin{tabular}{l|l} 
Exclusion: & - Articles not written in English \\
& - Articles not associated with canine caesarean sections or \\
& related to PICO \\
& - Case reports \\
& - Case studies \\
& Book chapters
\end{tabular}




\begin{tabular}{|l|l|}
\hline & - Literature reviews \\
\hline & - Conferences \\
\hline Inclusion: & - Meta-analysis \\
& - Systematic reviews \\
& - Randomised controlled study \\
\hline
\end{tabular}

\begin{tabular}{|c|c|c|c|c|c|c|c|c|}
\hline \multicolumn{9}{|c|}{ Search Outcome } \\
\hline Database & $\begin{array}{c}\text { Number } \\
\text { of } \\
\text { results }\end{array}$ & $\begin{array}{c}\text { Excluded } \\
\qquad- \\
\text { Literature } \\
\text { Review }\end{array}$ & $\begin{array}{c}\text { Excluded } \\
- \\
\text { Evaluated } \\
\text { alfaxalone } \\
\text { or } \\
\text { propofol } \\
\text { on its } \\
\text { own }\end{array}$ & $\begin{array}{c}\text { Excluded } \\
- \\
\text { Case } \\
\text { reports } \\
\text { and } \\
\text { studies }\end{array}$ & $\begin{array}{c}\text { Excluded } \\
- \\
\text { Book } \\
\text { chapters }\end{array}$ & $\begin{array}{c}\text { Excluded } \\
- \\
\text { Not } \\
\text { written in } \\
\text { English }\end{array}$ & $\begin{array}{c}\text { Excluded } \\
- \\
\text { Conferences }\end{array}$ & $\begin{array}{c}\text { Total } \\
\text { relevant } \\
\text { papers }\end{array}$ \\
\hline $\begin{array}{l}\text { CAB } \\
\text { Abstracts }\end{array}$ & 6 & 1 & 2 & 0 & 0 & 0 & 0 & 3 \\
\hline PubMed & 4 & 1 & 0 & 0 & 0 & 3 & 0 & 3 \\
\hline \multicolumn{8}{|c|}{ Total relevant papers when duplicates removed } & 3 \\
\hline
\end{tabular}

\section{CONFLICT OF INTEREST}

The authors declare no conflict of interest.

\section{REFERENCES}

1. Onclin, K.J. \& Verstegen, J.P. (2008). Cesarean Section in the Dog. Clinician's brief. 72-78.

2. Pascoe, P.J. \& Moon, P.F. (2001). Periparturient and neonatal anaesthesia. Veterinary Clinics of North America: Small Animal Practice. 31(2), 315-341. DOI: https://doi.org/10.1016/S0195-5616(01)50208-9

3. World Small Animal Veterinary Association Global Veterinary Community. Cesarean section.

4. Paddleford, R.R. (2016). Anesthesia for Ceserean Section in the Dog. Veterinary Clinics of North America: Small Animal Practice. 22(2), 481-484. DOI: https://doi.org/10.1016/S0195-5616(92)50678-7

5. Sams, L., Braun, C., Allman, D. \& Hofmeister, E. (2008). A comparison of the effects of propofol and etomidate on the induction of anaesthesia and on cardiopulmonary parameters in dogs. Veterinary Anaesthesisa and Analgesia. 35(6), 488-494.DOI: http://doi.org/1111/j.1467-2995.2008.00417.x

6. Luna, S.P.L., Cassu, R.N., Castro, G.B., Teixeira Neto, F.J., Silva Júnior, J.R. \& Lopes, M.D. (2004). Effects of four anaesthetic protocols on the neurological and cardiorespiratory variable of puppies born by caesarean section. Veterinary Record. 154(13), 387-389. DOI: https://doi.org/10.1136/vr.154.13.387 
7. Moon, P.F., Erb, H.N., Ludders, J.W., Gleed, R.D \& Pascoe, P.J. (2000). Perioperative risk factors for puppies delivered by cesarean section in the United States and Canada. Journal of the American Animal Hospital Association. 36(4), 359-68. DOI: https://doi.org/10.5326/15473317-36-4-359

8. Jurox Animal Health. (2013). What is Alfaxan ${ }^{\circledR}$ ? Alfaxan (alfaxalone $10 \mathrm{mg} / \mathrm{mL}$ ). Available at: https://jurox.com/sites/default/files/resources/juroxinc alfaxan whatisalfaxan ipad.pdf [Accessed May 2019].

9. Brewster, M.E., Estes, K.S. \& Bodor, N. (1989). Development of a non-surfactant formulation for alfaxalone through use of chemically-modified cyclodextrins. Journal of Parenteral Science and Technology. 43(6), 262-265.

10. Maney, J.K., Shepard, M.K., Braun, C., Cremer, J. \& Hofmeister, E.H. (2013). A comparison of cardiopulmonary and anesthetic effects of an induction dose of alfaxalone or propofol in dogs. Veterinary Anaesthesia and Analgesia. 40(3), 237-244. DOI: https://doi.org/10.1111/vaa.1200

11. Kanto, J.H. (1988). Propofol, the newest induction agent of anesthesia. International Journal of Clinical Pharmacology, Therapy and Toxicology. 26(1), 41-57.

12. Vilar, J.M., Batista, M., Perez, R., Zagorskaia, A., Jouanisson, E., Díaz-Bertrana, \& Rosales, S. (2018). Comparison of 3 anesthestic protocols for the elective cesarean-section in the dog: Effects on the bitch and the newborn puppies. Animal Reproduction Science. 190, 53-62.

DOI: https://doi.org/10.1016/i.anireprosci.2018.01.007

13. Ruiz, C.C., Del Carro, A.P., Rosset, E., Guyot, E., Maroiller, L., Buff, S. \& Portier, K. (2016). Alfaxalone for total intravenous anaesthesia in bitches undergoing elective caesarean section and its effects on puppies: a randomized clinical trial. Veterinary Anaesthesia and Analgesia. 43(3), 281-290. DOI: https://doi.org/10.1111/vaa.12298

14. Metcalfe, S., Hulands-Nave, A., Bell, M., Kidd, C., Pasloske, K., O'Hagan, B., Perkins, N. \& Whittem, T. (2014). Multicentre, randomised clinical trial evaluating the efficacy and safety of alfaxalone administered to bitches for induction of anaesthesia prior to caesarean section. Australian Veterinary Journal. 92(9), 333-338. DOI: https://doi.org/10.1111/avj.12223

15. Doebeli, A., Michel, E., Bettschart, R. Hartnack, S. \& Reichler, I.M. (2013). Apgar score after induction of anesthesia for canine cesarean section with alfaxalone versus propofol. 80(8), 850-854.

DOI: https://doi.org/10.1016/j.theriogenology.2013.07.006

16. Callander,, Antsey, A.V., Ingram, J.R., Limpens, J., Flohr, C. \& Spuls, P.I. (2017). How to write a Critically Appraised Topic: evidence to underpin routine clinical practice. British Journal of Dermatology. 177(4), 1007-1013. DOI: https://doi.org/10.1111/bjd.15873

17. Bang, H., Ni, L. \& Clarence, E.D. (2004). Assessment of blinding in clinical trials. Control Clinical Trials. 25(2), 143-156. DOI: https://doi.org/10.1016/i.cct.2003.10.016

18. Juni, P., Altman, D.G. \& Egger, M. (2001). Assessing the quality of controlled clinical trials. 323, 42-46. DOI: https://doi.org/10.1136/bmj.323.7303.42

19. Nayak, B.K. (2010).Understanding the relevance of sample size calculation. Indian Journal of Opthalmology. 58(6) , 469-470. DOI: https://doi.org/ 4103/0301-4738.71673

20. Mila, H., Grellet, A., Delebarre, M., Mariani, C., Feugier, A. \& Chastant-Maillard, S. (2017). Monitoring of the newborn dog and prediction of neonatal mortality. Preventive Veterinary Medicine. 143, 11-20. DOI: https://doi.org/10.1016/j.prevetmed.2017.05.005

21. Veronesi, M.C. (2016). Assessment of canine neonatal viability - the Apgar score. Reproduction in Domestic Animals. 51(S1), 46-50. DOI: https://doi.org/10.1111/rda.12787

22. Groppetti, D., Pecile, A., Del Carro, A.P., Copley, K., Minero, M. \& Cremonesi, F. (2010). Evaluation of newborn canine viability by means of umbilical vein lactate measurement, apgar score and uterine tocodynamometry. 74(7), 1187-1196. DOI: https://doi.org/10.1016/j.theriogenology.2010.05.020

23. WSAVA Global Pain Council Pain Management Protocol. (2014). Caesarean section. Journal of Small Animal Practice. 155, E10-E68.

24. Bolis, B., Prandi, A., Rota, A., Faustini, M. \& Veronesi, M.C. (2017). Cortisol fetal fluid concentrations in term pregnancy of small-sized purebred dogs and its preliminary relation to first 24 hours survival of newborns. 88, 264-269. DOI: http://doi.org/10.1016/j.theriogenology.2016.09.037 
25. Melandri, M., Alonge, S., Peric, T., Bolis, B. \& Veronesi, M.C. (2019). Effects of Alfaxalone or Propofol on Giant-Breed Dog Neonates Viability During Elective Caesarean Section. 9(11), 962.

DOI: https://doi.org/10.3390/ani9110962

26. De Cramer, K.G.M., Joubert, K.E. \& Nöthling, J.O. (2017). Puppy survival and vigor associated with the use of low dose medetomidine premedication, propofol induction and maintenance of anesthesia using sevoflurane gas-inhalation for cesarean section in the bitch. Theriogenology. 96, 10-15. DOI: https://doi.org/10.1016/i.theriogenology.2017.03.021 


\section{EVIIDEFeE

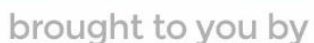 \\ RCVS KNOWLEDGE}

\section{Intellectual Property Rights}

Authors of Knowledge Summaries submitted to RCVS Knowledge for publication will retain copyright in their work, and will be required to grant RCVS Knowledge a non-exclusive license of the rights of copyright in the materials including but not limited to the right to publish, re-

publish, transmit, sell, distribute and otherwise use the materials in all languages and all media throughout the world, and to license or permit others to do so.

\section{Disclaimer}

Knowledge Summaries are a peer-reviewed article type which aims to answer a clinical question based on the best available current evidence. It does not override the responsibility

of the practitioner. Informed decisions should be made by considering such factors as individual clinical expertise and judgement along with patient's circumstances and owners' values. Knowledge Summaries are a resource to help inform and any opinions expressed within the Knowledge Summaries are the author's own and do not necessarily reflect the view of the RCVS Knowledge. Authors are responsible for the accuracy of the content. While the

Editor and Publisher believe that all content herein are in accord with current recommendations and practice at the time of publication, they accept no legal responsibility

for any errors or omissions, and make no warranty, express or implied, with respect to material contained within.

For further information please refer to our Terms of Use.

RCVS Knowledge is the independent charity associated with the Royal College of Veterinary Surgeons (RCVS). Our ambition is to become a global intermediary for evidence based veterinary knowledge by providing access to information

that is of immediate value to practicing veterinary professionals and directly contributes to evidence based clinical decision-making.

https://www.veterinaryevidence.org/

RCVS Knowledge is a registered Charity No. 230886.

Registered as a Company limited by guarantee in England and Wales No. 598443.

Registered Office: Belgravia House, 62-64 Horseferry Road, London SW1P 2AF

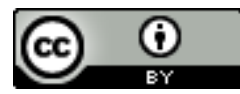

This work is licensed under a Creative Commons Attribution 4.0 International License 